OPEN ACCESS

Edited by:

Mike Taylor,

The University of Auckland

New Zealand

Reviewed by:

Sébastien Duperron,

Université Pierre et Marie Curie,

France

Timothy John Snelling,

University of Aberdeen, UK

*Correspondence:

Andreas Schramm

andreas.schramm@bios.au.dk

Specialty section:

This article was submitted to

Microbial Symbioses,

a section of the journal

Frontiers in Microbiology

Received: 06 February 2016

Accepted: 01 April 2016

Published: 26 April 2016

Citation:

Kroer P, Kjeldsen KU, Nyengaard JR,

Schramm A and Funch P (2016) A

Novel Extracellular Gut Symbiont in

the Marine Worm Priapulus caudatus

(Priapulida) Reveals an

Alphaproteobacterial Symbiont Clade

of the Ecdysozoa.

Front. Microbiol. 7:539

doi: 10.3389/fmicb.2016.00539

\section{A Novel Extracellular Gut Symbiont in the Marine Worm Priapulus caudatus (Priapulida) Reveals an Alphaproteobacterial Symbiont Clade of the Ecdysozoa}

\author{
Paul Kroer ${ }^{1}$, Kasper U. Kjeldsen ${ }^{2}$, Jens R. Nyengaard ${ }^{3}$, Andreas Schramm ${ }^{2 *}$ and \\ Peter Funch ${ }^{1}$ \\ ${ }^{1}$ Section for Genetics, Ecology, and Evolution, Department of Bioscience, Aarhus University, Aarhus, Denmark, ${ }^{2}$ Section for \\ Microbiology and Center for Geomicrobiology, Department of Bioscience, Aarhus University, Aarhus, Denmark, ${ }^{3}$ Stereology \\ and Electron Microscopy Laboratory, Department of Clinical Medicine, Centre for Stochastic Geometry and Advanced \\ Bioimaging, Aarhus University, Aarhus, Denmark
}

Priapulus caudatus (phylum Priapulida) is a benthic marine predatory worm with a cosmopolitan distribution. In its digestive tract we detected symbiotic bacteria that were consistently present in specimens collected over 8 years from three sites at the Swedish west coast. Based on their 16S rRNA gene sequence, these symbionts comprise a novel genus of the order Rickettsiales (Alphaproteobacteria). Electron microscopy and fluorescence in situ hybridization (FISH) identified them as extracellular, elongate bacteria closely associated with the microvilli, for which we propose the name "Candidatus Tenuibacter priapulorum". Within Rickettsiales, they form a phylogenetically well-defined, family-level clade with uncultured symbionts of marine, terrestrial, and freshwater arthropods. Cand. Tenuibacter priapulorum expands the host range of this candidate family from Arthropoda to the entire Ecdysozoa, which may indicate an evolutionary adaptation of this bacterial group to the microvilli-lined guts of the Ecdysozoa.

Keywords: Rickettsiales, invertebrate-bacteria symbiosis, Ecdysozoa, microvilli, Priapulus caudatus, gut symbiont

\section{INTRODUCTION}

Priapulus caudatus (Lamarck 1816) is a marine worm inhabiting soft bottom sediments. It belongs to the Priapulida, a small phylum with 19 known extant species (Schmidt-Rhaesa, 2012). The priapulids have a long fossil history with so-called stem-priapulids dating back to the midCambrian (e.g., Huang et al., 2004), and some species, including P. caudatus, show little apparent morphological change since the Cambrian. The phylum belongs to the Scalidophora along with Kinorhyncha and Loricifera nested inside the major protostome taxon Ecdysozoa, the molting invertebrates (Aguinaldo et al., 1997). The members of Ecdysozoa are most notably characterized by the regular shedding of a cuticle (ecdysis) and comprise, among smaller phyla, the well-known arthropods and nematodes (for an overview, see Figure S1). The taxon Ecdysozoa is important for understanding the basal phylogeny of animals and has become well-established in metazoan taxonomy (e.g., Edgecombe et al., 2011). 
P. caudatus can be found all over the northern hemisphere in low abundance and is an opportunistic predator and scavenger, preying on other invertebrates such as annelids and crustaceans (Vannier, 2012). Although it is the earliest described and most studied priapulid (Schmidt-Rhaesa, 2012), and despite the important role of symbiotic bacteria in a wide range of invertebrate hosts (reviewed in e.g., Dubilier et al., 2008; Nyholm and Graf, 2012), there is so far only a single report addressing a putative microbial symbiosis in $P$. caudatus: by transmission electron microscopy (TEM), McLean (1985) observed elongate bacterial cells associated with the microvilli in the intestinal lumen of two specimens of $P$. caudatus from Orcas Island, Northwest Pacific, USA. Bacteria were also observed within vacuoles of host intestinal cells but it could not be determined if these were different bacteria or whether they were undergoing digestion. While gut symbionts in certain arthropods, especially insects such as aphids and termites have been well investigated (Engel and Moran, 2013; Hansen and Moran, 2014), almost nothing is known about identity and function of gut symbionts in scalidophorans, including P. caudatus. The goal of the present study was to localize and identify these putative intestinal symbionts by $16 \mathrm{~S}$ rRNA gene cloning and sequencing, TEM, and fluorescence in situ hybridization (FISH).

\section{MATERIALS AND METHODS}

\section{Living Material, Sampling, and Fixation}

Two adult $P$. caudatus specimens were collected in 2011 from soft sediments at 35-60 m water depth from Gullmarsfjorden (Fiskebäckskil), Sweden (Figure 1) with a ring dredge. They were dissected in filtered sea water; the gut was cut open longitudinally and rinsed thoroughly to remove gut content. The gut of one specimen was fixed for TEM in $2 \%$ glutaraldehyde buffered with $0.2 \mathrm{M}$ sodium cacodylate and $0.275 \mathrm{M}$ sucrose for $3 \mathrm{~h}$ at $5^{\circ} \mathrm{C}(\mathrm{pH}$ at 7.4$)$, washed in $0.27 \mathrm{M}$ sodium cacodylate with $0.37 \mathrm{M}$ sucrose, post-fixed in $1 \%$ osmium tetroxide for $1 \mathrm{~h}$ and stored in ethanol at $-18^{\circ} \mathrm{C}$. The other gut was split longitudinally into two subsamples; one was fixed for FISH in $4 \%(\mathrm{w} / \mathrm{v})$ paraformaldehyde in phosphate buffered saline (PBS, $130 \mathrm{mM} \mathrm{NaCl}, 10 \mathrm{mM}$ Na-phosphate buffer, $\mathrm{pH} 7.4$ ) at $4^{\circ} \mathrm{C}$ for $1 \mathrm{~h}$, washed in PBS, and stored in ethanol at $-20^{\circ} \mathrm{C}$, the other was preserved for DNA extraction in TE buffer $(10 \mathrm{mM}$ Tris, $1 \mathrm{mM}$ EDTA, pH 8.0). Mid-gut tissue samples from three P. caudatus specimens preserved in ethanol were obtained from Gothenburg Natural History Museum for additional DNA extractions. These specimens had been sampled from three different locations on the Swedish west coast in the years 2004, 2007, and 2008 (Figure 1).

\section{DNA Extraction}

DNA was extracted from the fresh samples using the DNeasy Blood and Tissue kit (Qiagen) according to the manufacturer's protocol. Ethanol-fixed samples were extracted in duplicate using the same kit with the following modifications: residual ethanol was removed by evaporation at room temperature prior to extraction; DNA yield was maximized by (i) incubating the eluent buffer $(50 \mu \mathrm{l})$ in the DNA-binding filter column for $10 \mathrm{~min}$,

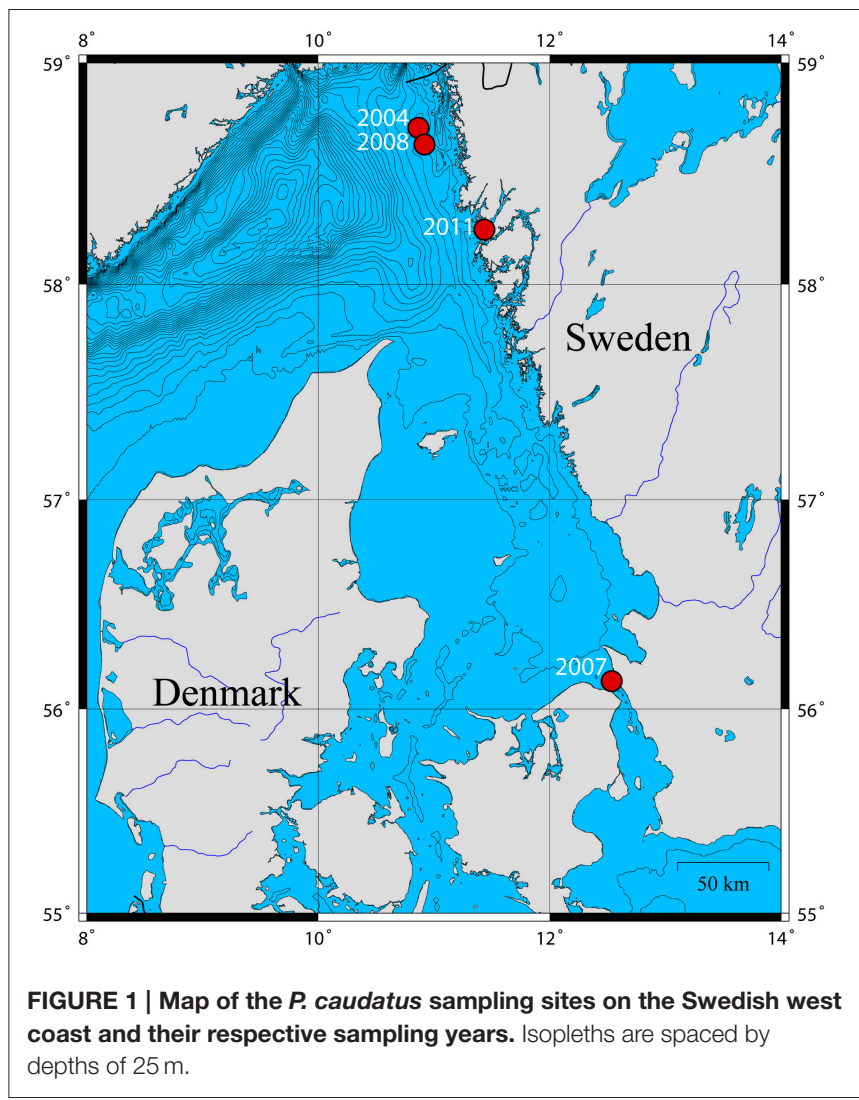

(ii) repeating the elution twice, and (iii) combining all eluent fractions from the duplicate extractions and concentrating the DNA extract to a final volume of $100 \mu \mathrm{l}$ in a vacuum centrifuge (miVac DNA Concentrator, GeneVac ltd.).

\section{PCR, Cloning, and Sequencing}

Near full-length 16S rRNA genes were amplified in 27 PCR cycles with Taq Master Mix RED (Ampliqon A/S) and the general bacterial primer $8 \mathrm{~F}$ with ambiguities, $616 \mathrm{~V}$ according to Juretschko et al. (1998) (5'-AGA GTT TGA TYM TGG CTC AG-3') and universal primer Uni1492R (5'-GGY TAC CTT GTT ACG ACT T-3'; Loy et al., 2002) at an annealing temperature of $52^{\circ} \mathrm{C}$. PCR products were cloned into E. coli JM109 using the pGEM-T vector system (Promega), and 168 clones were selected (96 from the fresh 2011 sample and 24 clones from each of the ethanol fixed samples) for partial Sanger sequencing (GATC Biotech). A few clones representing the phylotype of the putative symbiont were selected from each clone library for almost full-length sequencing. The $16 \mathrm{~S}$ rRNA gene sequences of the symbiont were deposited in GenBank under the accession numbers KP138714, KP138715, KP138716 (full-lengths), and KU195266 (900 bp).

\section{Phylogenetic Analysis}

Sequences were trimmed to remove primer and vector bases, aligned with the SINA web aligner (Pruesse et al., 2012) and added to the alignment of the SILVA SSURef v115 ARB database (Quast et al., 2013) along with their most closely related 
sequences as identified by the basic local alignment search tool (BLAST; Johnson et al., 2008); the alignments were corrected manually in ARB (Ludwig et al., 2004). Representative sequences were further analyzed using Bayesian Inference (BI) and Maximum Likelihood (ML) methods. BI analysis was performed in MrBayes (Huelsenbeck and Ronquist, 2001), applying a general time-reversible (GTR) model of substitution with a proportion of invariable sites and gamma distributed among-site rate variation $(\mathrm{GTR}+\mathrm{I}+\Gamma)$. The number of generations was set to 3 million with a sampling and printing frequency of 200 . All other settings remained at default, i.e., two runs were carried out in parallel. Runs converged at a standard deviation of 0.0034 , and the resultant full tree is shown in Figure S2.
ML analysis was performed with RaxML v. 7.0.3 (Stamatakis, 2006) implemented in the ARB software. A GTR $+\mathrm{I}+\Gamma$ model was chosen with rapid bootstrap analysis of 5000 runs. The resultant full phylogenetic tree is shown in Figure S3. A simplified consensus tree was constructed based on the BI tree and incongruences with the ML tree are shown as multifurcations (Figure 2). Tree visualizations were done using the FigTree software (v1.4).

\section{Light Microscopy and TEM}

The glutaraldehyde fixed sample was dehydrated using graded ethanol series and acetone and embedded in an epoxy resin (kit 812 (Epon) from TAAB Laboratories Equipment ltd.)

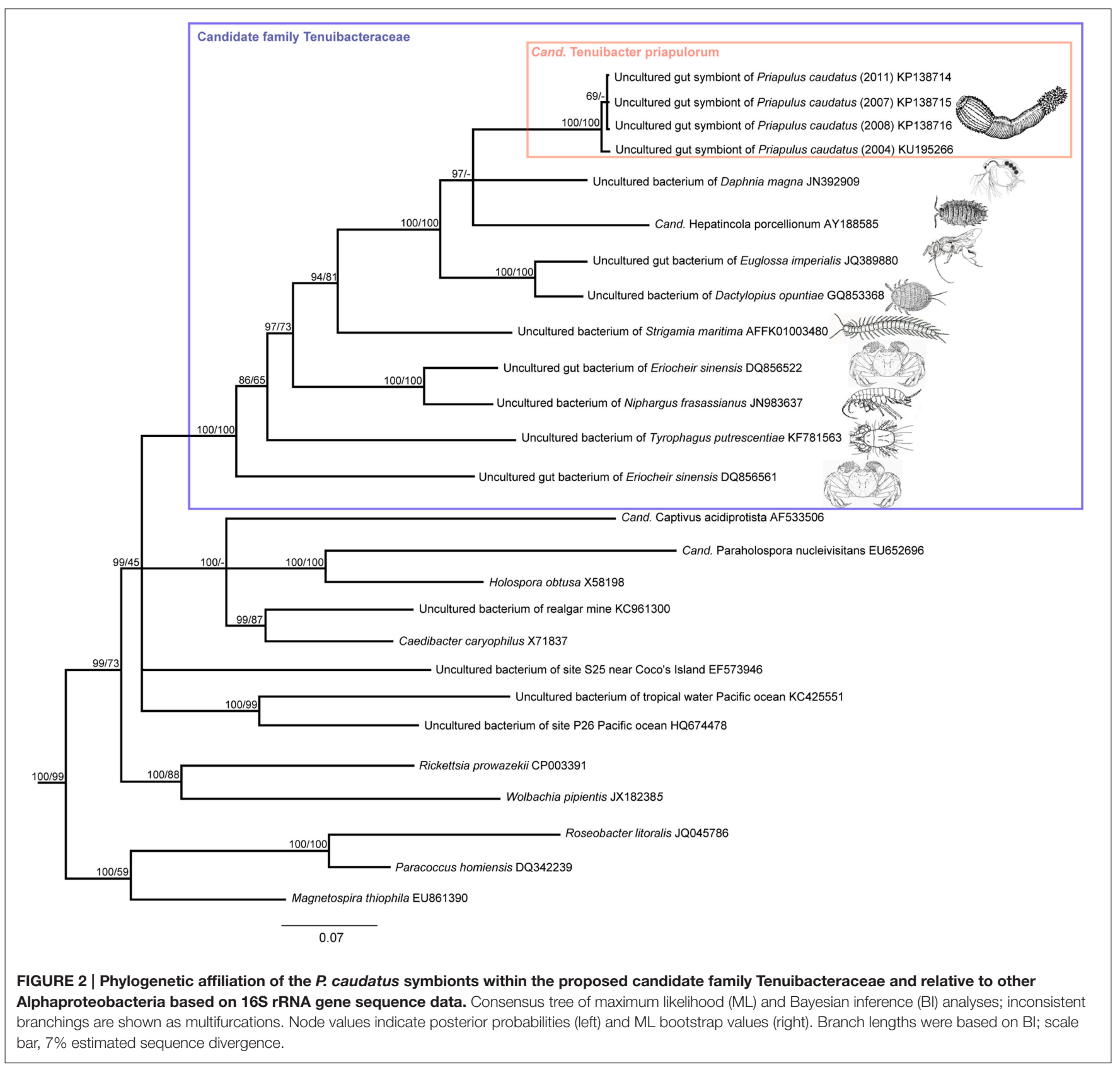


using acetone as an intermedium, and sectioned with an ultramicrotome. Semi-thin sections were stained with toluidine blue and mounted on microslides for light microscopy on an Olympus BX60 with an attached Olympus XC30 camera. Micrographs were composed using the multi-image alignment tool of the CellSens 1.7 software (Olympus Soft Imaging Solutions $\mathrm{GmbH}$ ).

Ultrathin sections were collected on Formwar-coated grids with $1 \times 2 \mathrm{~mm}$ slots, stained with Ultrostain-1 (stabilized solution with $0.5 \%$ uranyl acetate; Leica microsystems) for 10 min, rinsed in distilled water, stained for 5 min with lead nitrate/sodium citrate ( $\mathrm{pH} 12$; Ampliqon A/S), and examined on a Phillips Morgani 268 microscope using a high voltage of $80 \mathrm{kV}$; digital micrographs were obtained with an attached MegaView III SIS camera.

\section{FISH}

Using the probe design feature of the ARB software, an oligonucleotide probe, PricSym652 (5'-TATCCCCTTCTGTTC TCT-3', spanning E. coli 16S rRNA gene positions 652-669), was designed to specifically target the $16 \mathrm{~S}$ rRNA of the putative $P$. caudatus symbiont. Probe specificity and hybridization characteristics were evaluated in silico using the "probecheck" tool (Loy et al., 2008) and the "mathFISH" software (Yilmaz et al., 2011). The probe had two central mismatches to the closest non-target sequence in the database, a Firmicutes-affiliated clone

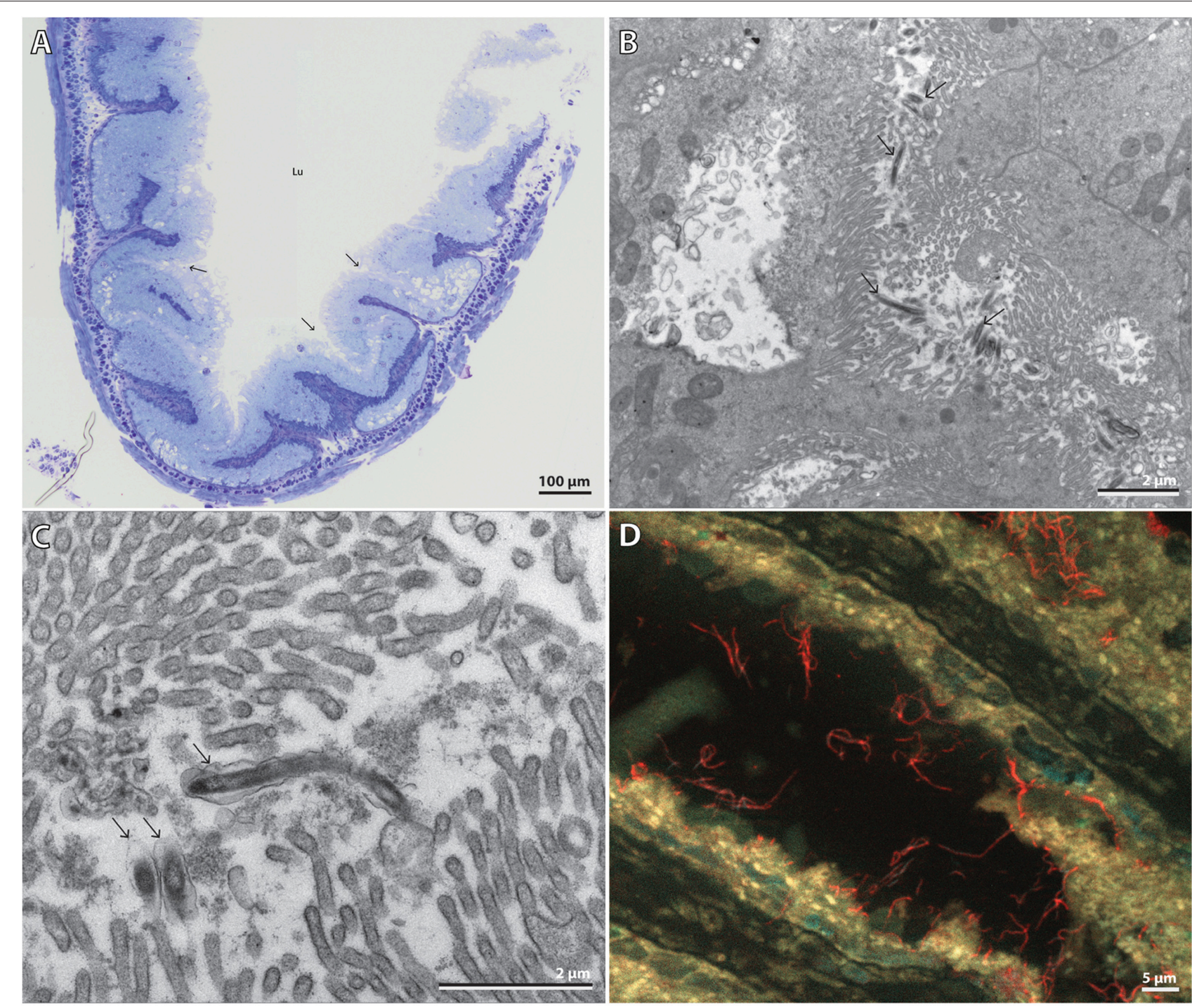

FIGURE 3 | (A) Composite light microscopy image of half of a gut cross-section. Arrows point to the "pocket structures" where the symbionts were observed. Lu = gut lumen. Scale bar, $100 \mu \mathrm{m}$. (B) TEM micrograph of partially-visible elongated bacterial cells among host microvilli within pockets formed by the gut epithelium. Arrows point to various bacteria. Scale bar, $2 \mu \mathrm{m}$. (C) TEM micrograph close-up of three bacteria, one almost fully visible. Arrows point to the bacteria. Scale bar, 2 $\mu \mathrm{m}$. (D) Extended focus multi-channel epifluorescence micrograph of a gut section hybridized with the symbiont-specific probe PricSym652-CY3 and stained with DAPI. Cand. T. priapulorum symbionts appear red, host nuclei cyan, and autofluorescent host tissue yellow. Scale bar, $5 \mu \mathrm{m}$. 
sequence. A melting formamide concentration, $[\mathrm{FA}]_{\mathrm{m}}$, of $46.2 \%$ at $46^{\circ} \mathrm{C}$ in standard FISH buffer was predicted by mathFISH, and FISH with a formamide series (40-60\% with increments of $5 \%$ ) confirmed signal drop-off $>45 \%$ formamide; therefore $45 \%$ formamide was chosen for specific hybridization.

The paraformaldehyde-fixed sample was washed in PBS and divided into several subsamples, which were embedded overnight in Tissue Freezing Medium ${ }^{\circledR}$ (Jung) and sectioned at $-14^{\circ} \mathrm{C}$ on a cryomicrotome (Leica CM 1850). The $10 \mu \mathrm{m}$ thick sections were collected on SuperFrost ${ }^{\circledR}$ slides, washed in Milli-Q water (Millipore) to remove the embedding, and dehydrated in a graded ethanol series. A ring was drawn on the slides around the tissue section with a hydrophobic pen (Pap-Pen, Kisker) to create a hybridization well. DOPE-FISH was performed as previously described (Stoecker et al., 2009), with hybridization times of at least 2 h. Probes EUB338, EUB-II, EUB-III (Daims et al., 1999), and NON (Manz et al., 1992) were used as positive and negative controls, and probe ALF1b (Manz et al., 1992) to ensure specific detection of the alfaproteobacterial symbionts; all probes were synthesized and double-labeled with CY3 or CY5 by Biomers (biomers.net). Hybridized samples were mounted in Citifluor/Vectashield (4:1) containing $1 \mu \mathrm{g} \mathrm{ml}^{-1}$ of DAPI and imaged on an Axiovert $200 \mathrm{M}$ microscope (Carl Zeiss) with attached AxioCam MRm camera and Apotome module, using AxioVision 4.8 software.

\section{RESULTS AND DISCUSSION}

\section{A Specific Symbiont in the Midgut of Priapulus caudatus}

Each of the clone libraries derived from four $P$. caudatus specimens collected in 4 different years at three distinct sites at the Swedish west coast were strongly dominated by a single phylotype, with all 96 clones, or 24, 22, and 21 of the 24 clones analyzed, showing $\geq 99.3 \% 16 \mathrm{~S}$ rRNA gene sequence identity. The closest described relative ( $88 \%$ sequence identity) of the $P$. caudatus-specific phylotype was "Candidatus Hepatincola porcellionum," an uncultured extracellular symbiont in the midgut gland (hepatopancreas) of the rough woodlouse Porcellio scaber (Wang et al., 2004), and a member of the alphaproteobacterial order Rickettsiales (Figure 2). The most similar sequences from environmental (non-host-associated) sources were from marine waters but were only $<84 \%$ identical to the P. caudatus phylotype (Figure 2). Only three additional phylotypes were found in two of the four specimens. In the 2007 specimen three clone sequences were $89 \%$ identical to an uncultured bacterium from a cold seep microbial mat, and $83 \%$ identical to Spiroplasma eriocheiris [Genbank accession number (acc. nr.): KU878561]. Also in this specimen one clone was found with $84 \%$ sequence identity to an uncultured bacterium or chloroplast from coral tissue (acc. nr: KU878562). In the 2008 specimen two clones were found with $99 \%$ sequence identity to Thermus scotoductus (acc. nr: KU878563).

Light microscopy and TEM of $P$. caudatus midgut sections showed a straight gut consisting of uniform epithelial cells with a microvillous border apically. Cilia and cuticular structures were absent. The gut epithelium was annulated and folded, forming "pockets" where the microvilli from adjacent folds came into contact (Figure 3A). TEM revealed uniform bacterial cells located among microvilli within such folds, and therefore only partially visible (Figures 3B,C), in agreement with the previous observation by McLean (1985). Their morphology was similar to that of the microvilli, i.e., elongated slightly curved rods, $0.2 \times \geq 3.5 \mu \mathrm{m}$ in size, and surrounded by an outer folded membrane-like structure, although this may be a sample preparation artifact (Figure 3C). The ultrastructure of the host

TABLE 1 | Distance matrix of 16S rRNA gene identities (in \%) for all members of the candidate family Tenuibacteraceae (1-13) and the type species of Holosporaceae (14) and Rickettsiaceae (15).

\begin{tabular}{|c|c|c|c|c|c|c|c|c|c|c|c|c|c|c|}
\hline & 1 & 2 & 3 & 4 & 5 & 6 & 7 & 8 & 9 & 10 & 11 & 12 & 13 & 14 \\
\hline 1 & 100 & & & & & & & & & & & & & \\
\hline 2 & 99.8 & 100 & & & & & & & & & & & & \\
\hline 3 & 99.8 & 99.7 & 100 & & & & & & & & & & & \\
\hline 4 & 99.5 & 99.3 & 99.3 & 100 & & & & & & & & & & \\
\hline 5 & 89.6 & 89.5 & 89.7 & 88.9 & 100 & & & & & & & & & \\
\hline 6 & 88.0 & 87.8 & 87.9 & 87.3 & 88.5 & 100 & & & & & & & & \\
\hline 7 & 88.6 & 88.4 & 88.5 & 87.3 & 88.3 & 87.4 & 100 & & & & & & & \\
\hline 8 & 88.8 & 88.7 & 88.9 & 88.2 & 88.5 & 87.7 & 95.1 & 100 & & & & & & \\
\hline 9 & 85.5 & 85.4 & 85.5 & 85.0 & 85.7 & 84.6 & 85.4 & 85.7 & 100 & & & & & \\
\hline 10 & 85.1 & 85.1 & 85.2 & 84.1 & 85.3 & 83.8 & 84.5 & 84.7 & 85.4 & 100 & & & & \\
\hline 11 & 85.3 & 85.1 & 85.1 & 83.8 & 85.0 & 83.3 & 84.7 & 84.8 & 85.3 & 93.3 & 100 & & & \\
\hline 12 & 84.6 & 84.6 & 84.6 & 84.4 & 84.1 & 81.5 & 84.1 & 84.3 & 85.3 & 84.4 & 84.5 & 100 & & \\
\hline 13 & 82.4 & 82.3 & 82.4 & 82.4 & 83.5 & 80.9 & 82.9 & 82.7 & 84.8 & 84.6 & 84.9 & 84.0 & 100 & \\
\hline 14 & 81.8 & 81.6 & 81.7 & 82.1 & 80.5 & 80.6 & 80.2 & 81.3 & 82.7 & 81.7 & 81.5 & 82.0 & 81.6 & 100 \\
\hline 15 & 80.6 & 80.6 & 80.7 & 79.4 & 82.2 & 79.8 & 80.8 & 83.5 & 81.9 & 81.9 & 81.6 & 81.9 & 81.8 & 83.4 \\
\hline
\end{tabular}

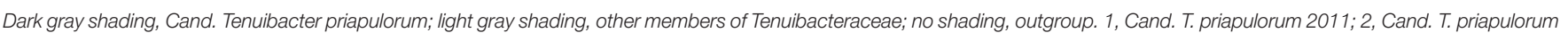

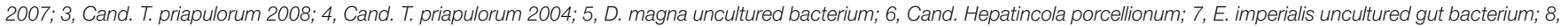

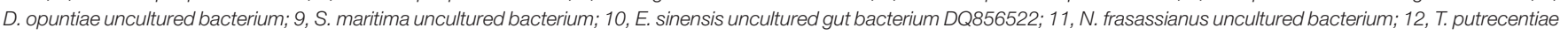
uncultured bacterium; 13, E. sinensis uncultured gut bacterium DQ856561; 14, Holospora obtusa; 15, Rickettsia prowazekii. 
gut cells did not show any signs of necrosis; likewise, the bacterial cells appeared fully intact, suggesting that they were unaffected by the strongly proteolytic digestive fluids of the host (Nilsson and Fänge, 1967).

FISH with the specific probe PricSym652 identified these bacteria as being cells of the P. caudatus-specific phylotype and revealed, by extended-focus imaging, that many cells were $\geq 5$ $\mu \mathrm{m}$ long (Figure 3D). Their affiliation to Alphaproteobacteria was confirmed with probe ALF1b (data not shown); few, if any, other bacterial cells were detected by FISH with the general bacterial probe or by DAPI staining (Figure S4), indicating that almost all other gut bacteria had been removed along with the gut content in the washing steps during gut preparation.

We acknowledge that only a small number of $P$. caudatus specimens has been analyzed due to the difficulty in sampling more animals. However, they were collected in different years and

TABLE 2 | Taxonomy and ecology of host animals of the candidate family Tenuibacteraceae, and origin of their putative symbiont sequence.

\begin{tabular}{|c|c|c|c|c|}
\hline $\begin{array}{l}\text { Host } \\
\text { (vernacular } \\
\text { names) }\end{array}$ & Taxonomy & Habitat & Diet & $\begin{array}{l}\text { Tenuibacteraceae } \\
\text { sequence origin }\end{array}$ \\
\hline $\begin{array}{l}\text { Priapulus } \\
\text { caudatus } \\
\text { (Penis worm) }\end{array}$ & Priapulida & $\begin{array}{l}\text { Marine } \\
\text { (benthic) }\end{array}$ & $\begin{array}{l}\text { Generalist } \\
\text { predator and } \\
\text { scavenger }\end{array}$ & Midgut \\
\hline $\begin{array}{l}\text { Porcellio scaber } \\
\text { (Rough } \\
\text { woodlouse) }\end{array}$ & $\begin{array}{l}\text { Arthropoda, } \\
\text { Crustacea, } \\
\text { Oniscidea }\end{array}$ & Terrestrial & $\begin{array}{l}\text { Detritus, } \\
\text { mainly plant } \\
\text { litter }\end{array}$ & $\begin{array}{l}\text { Hepatopancreas } \\
\text { (digestive tract) }\end{array}$ \\
\hline $\begin{array}{l}\text { Daphnia magna } \\
\text { (Water flea) }\end{array}$ & $\begin{array}{l}\text { Arthropoda, } \\
\text { Crustacea, } \\
\text { Cladocera }\end{array}$ & $\begin{array}{l}\text { Freshwater/ } \\
\text { brackish }\end{array}$ & $\begin{array}{l}\text { Phytoplankton, } \\
\text { filter-feeder }\end{array}$ & Unknown \\
\hline $\begin{array}{l}\text { Euglossa } \\
\text { imperialis } \\
\text { (Orchid bee) }\end{array}$ & $\begin{array}{l}\text { Arthropoda, } \\
\text { Insecta, } \\
\text { Euglossini }\end{array}$ & Terrestrial & $\begin{array}{l}\text { Nectar and } \\
\text { pollen }\end{array}$ & Whole gut \\
\hline $\begin{array}{l}\text { Dactylopius } \\
\text { opuntiae } \\
\text { (Cochineal) }\end{array}$ & $\begin{array}{l}\text { Arthropoda, } \\
\text { Insecta, } \\
\text { Coccoidea }\end{array}$ & Terrestrial & Plant sap & Entire specimen \\
\hline $\begin{array}{l}\text { Eriocheir } \\
\text { sinensis } \\
\text { (Chinese mitten } \\
\text { crab) }\end{array}$ & $\begin{array}{l}\text { Arthropoda, } \\
\text { Crustacea, } \\
\text { Brachyura }\end{array}$ & $\begin{array}{l}\text { Freshwater/ } \\
\text { brackish } \\
\text { (benthic) }\end{array}$ & Omnivore ${ }^{a}$ & Whole gut \\
\hline $\begin{array}{l}\text { Niphargus } \\
\text { frasassianus } \\
\text { (Amphipod) }\end{array}$ & $\begin{array}{l}\text { Arthropoda, } \\
\text { Crustacea, } \\
\text { Amphipoda }\end{array}$ & $\begin{array}{l}\text { Freshwater/ } \\
\text { in caves } \\
\text { (troglobitic) }\end{array}$ & $\begin{array}{l}\text { Likely omni- } \\
\text { and detritivore }\end{array}$ & Appendages $^{b}$ \\
\hline $\begin{array}{l}\text { Strigamia } \\
\text { maritima } \\
\text { (Centipede) }\end{array}$ & $\begin{array}{l}\text { Arthropoda, } \\
\text { Myriapoda, } \\
\text { Chilopoda }\end{array}$ & $\begin{array}{l}\text { Terrestrial/ } \\
\text { marine } \\
\text { (littoral) }\end{array}$ & $\begin{array}{l}\text { Predator of } \\
\text { marine } \\
\text { invertebrates }\end{array}$ & $\begin{array}{l}\text { Whole genome } \\
\text { sequencing of host }\end{array}$ \\
\hline $\begin{array}{l}\text { Tyrophagus } \\
\text { putrescentiae }^{\mathrm{c}} \\
\text { (Mold mite) }\end{array}$ & $\begin{array}{l}\text { Arthropoda, } \\
\text { Arachnida, } \\
\text { Acari }\end{array}$ & Terrestrial & $\begin{array}{l}\text { Primarily } \\
\text { fungivorous, } \\
\text { pest of stored } \\
\text { goods }\end{array}$ & $\begin{array}{l}\text { Entire female } \\
\text { specimen }\end{array}$ \\
\hline
\end{tabular}

a Tenuibacteraceae sequence were only found in aquaculture crabs fed innards and aquatic invertebrates (Li et al., 2007); these may have been the actual symbiont source, which would explain the recovery of two distinct symbiont sequences from the mitten crabs.

${ }^{b}$ During a study targeting sulfur-oxidizing epibionts in the appendages (Bauermeister et al., 2012), a single Tenuibacteraceae sequence from a single specimen was obtained, which may have originated from contamination with fecal material during dissection.

cPutative symbiont sequence misclassified in the original publication (Qu et al., 2014) as Tistrella sp. from distinct sites, and all of them contained the P. caudatusspecific phylotype. These putative symbionts showed a physical association to the gut epithelium strong enough to resist removal along with the general microbiota, caused no apparent damage to host tissue, and were not digested by the host; occasional phagocytosis may still be possible, as McLean (1985) observed yet unidentified bacteria in vacuoles in the intestinal cells. These collective findings indicate a stable, specific symbiosis of beneficial or commensal nature between the novel phylotype and $P$. caudatus.

Based on $<90 \% 16 \mathrm{~S}$ rRNA gene sequence identity to their closest relatives (Table 1), the symbionts represent a new species within a new genus (Yarza et al., 2014). Together with their specific identification by FISH with probe PricSym652, morphological description as elongate, curved rods of $0.2 \times$ $5 \mu \mathrm{m}$ size, their specific habitat in the gut of $P$. caudatus, and in accordance with the recommendations of Stackebrandt et al. (2002), we propose a new candidate genus and species for these as yet uncultured symbionts, with the name "Candidatus Tenuibacter priapulorum” gen. nov., sp. nov. [Te'nu.i.bac'ter. pri.a.pu.lo'rum. L. adj. tenuis, slender; Gr. n. bacter, rod; L. priapulorum, gen. pl. of Priapulus: slender rod-shaped bacterium belonging to the genus Priapulus].

\section{A Novel Clade of Putative Gut Symbionts}

Cand. Tenuibacter priapulorum clusters within a well-defined but previously unrecognized clade of the order Rickettsiales (Alphaproteobacteria; Figure 2); with 16S rRNA sequence identities of $<83 \%$ to its sister clades (Table 1), this newly defined clade represents a novel family (Yarza et al., 2014), for which we propose the candidate name Tenuibacteraceae.

This candidate family hitherto exclusively consisted of arthropod-associated-bacterial taxa. Except for the mitten crab Eriocheir sinensis, that contained two different sequence types, each arthropod host species appeared to harbor only one specific member of the clade. However, the crabs had been reared in aquaculture and fed other aquatic animals and innards (Li et al., 2007); thus the feed rather than the crab might be the actual source of the sequences, and the associations within the clade may still be species-specific symbioses. Host phylogenies did not correspond to the phylogenies of the respective putative symbionts (Figure 2 and Figure S1), suggesting that host and symbiont have not co-speciated. Vertical symbiont transfer and acquisition from arthropod prey may be possible, and may even have been the route of (an ancient) acquisition for the symbiont of the $P$. caudatus, given its terminal position in the symbiont clade (Figure 2), while the priapulid host is basal relative to arthropods (e.g., Borner et al., 2014 and Figure S1).

Many members of the Rickettsiales are intracellular symbionts (Fredricks, 2006), including Holosporaceae, the sister group of the newly defined clade, which consists of intranuclear symbionts of protists (Fredricks, 2006; Eschbach et al., 2009). The actual habitat or life style of the candidate family Tenuibacteraceae is less clear: sequences of five of its ten members were recovered from the digestive tract of arthropods and priapulids, while the remainder originated from unidentified tissues of whole arthropod specimens, including their gut (Table 2). The limited information available from Cand. Tenuibacter priapulorum, the 
woodlouse symbiont Cand. Hepatincola porcellionum (Wang et al., 2004), the orchid bee Euglossa imperialis (Koch et al., 2013) and the mitten crab (Li et al., 2007), however, suggests that members of candidate Tenuibacteraceae are extracellular digestive tract symbionts; their function remains elusive, also because of the vastly different habitats, lifestyles, and feeding modes of their hosts (Table 2). In general, gut symbioses of arthropods, best studied in insects (Engel and Moran, 2013), show large differences in symbiont diversity and function, precluding unifying predictions.

With the addition of $P$. caudatus, the host range of the symbiont clade is expanded from Arthropoda to Ecdysozoa. It is important to note that the members of Ecdysozoa have microvilli-lined guts rather than cilia-lined as is the norm among other protostome animals (Giribet et al., 2000; Pechenik, 2015). Given the very different ecologies of the various hosts (Table 2), microvilli-lined guts may be their only common feature. Together with the similar elongate morphology and tissue affinity of Cand. Tenuibacter priapulorum and Cand. Hepatincola porcellionum (no data are available for the other symbionts), this observation suggests that the symbionts require microvilli to adhere and interact with their hosts and their hostrange is limited to Ecdysozoa.

\section{AUTHOR CONTRIBUTIONS}

PF, AS, and KK conceived the study and designed the work; PK, $\mathrm{KK}, \mathrm{PF}, \mathrm{JN}$, and AS performed experimental work; PK, KK, and

\section{REFERENCES}

Aguinaldo, A. M., Turbeville, J. M., Linford, L. S., Rivera, M. C., Garey, J. R., Raff, R. A., et al. (1997). Evidence for a clade of nematodes, arthropods and other moulting animals. Nature 29, 387, 489-493.

Bauermeister, J., Ramette, A., and Dattagupta, S. (2012). Repeatedly evolved host-specific ectosymbioses between sulfur-oxidizing bacteria and amphipods living in a cave ecosystem. PLoS ONE 7:e50254. doi: 10.1371/journal.pone. 0050254

Borner, J., Rehm, P., Schill, R. O., Ebersberger, I., and Burmester, T. (2014). A transcriptome approach to ecdysozoan phylogeny. Mol. Phyl. Evol. 80, 79-87. doi: 10.1016/j.ympev.2014.08.001

Daims, H., Brühl, A., Amann, R., Schleifer, K. H., and Wagner, M. (1999). The domain-specific probe EUB338 is insufficient for the detection of all Bacteria: development and evaluation of a more comprehensive probe set. Syst. Appl. Microbiol. 22, 434-444. doi: 10.1016/S0723-2020(99)80053-8

Dubilier, N., Bergin, C., and Lott, C. (2008). Symbiotic diversity in marine animals: the art of harnessing chemosynthesis. Nat. Rev. Microbiol. 6, 725-740. doi: 10.1038/nrmicro1992

Engel, P., and Moran, N. A. (2013). The gut microbiota of insects - diversity in structure and function. FEMS Microbiol. Rev. 37, 699-735. doi: 10.1111/15746976.12025

Eschbach, E., Pfannkuchen, M., Schweikert, M., Drutschmann, D., Brümmer, F., Fokin, S., et al. (2009). "Candidatus Paraholospora nucleivisitans," an intracellular bacterium in Paramecium sexaurelia shuttles between the cytoplasm and the nucleus of its host. Syst. Appl. Microbiol. 32, 490-500. doi: 10.1016/j.syapm.2009.07.004

Edgecombe, G. D., Giribet, G., Dunn, C. W., Hejnol, A., Kristensen, R. M., Neves, R. C., et al. (2011). Higher-level metazoan relationships: recent progress and remaining questions. Org. Divers. Evol. 11, 151-172. doi: 10.1007/s13127-011$0044-4$
AS analyzed molecular data; all authors discussed and interpreted the results; PK, PF, and AS wrote the paper with editorial help of $\mathrm{KK}$ and $\mathrm{JN}$.

\section{FUNDING}

This study was funded by grants of the EU FP7 ASSEMBLE programme and the Danish Council for Independent Research Natural Sciences to AS, and by the Danish National Research Foundation. The Centre for Stochastic Geometry and Advanced Bioimaging is supported by the Villum Foundation.

\section{ACKNOWLEDGMENTS}

We thank Britta Poulsen, Susanne Nielsen, and Anette Berg for excellent technical assistance, Kennet Lundin, Gothenburg Natural History Museum, for supplying P. caudatus gut tissue samples and Bengt Lundve, Sven Lovén Centre for Marine Sciences, Kristineberg, Sweden) for sampling live specimens of $P$. caudatus.

\section{SUPPLEMENTARY MATERIAL}

The Supplementary Material for this article can be found online at: http://journal.frontiersin.org/article/10.3389/fmicb. 2016.00539
Fredricks, D. N. (2006). Introduction to the Rickettsiales and other intracellular prokaryotes. Prokaryotes 5, 457-466. doi: 10.1007/0-387-30745-1_18

Giribet, G., Distel, D. L., Polz, M., Sterrer, W., and Wheeler, W. C. (2000). Triploblastic relationships with emphasis on the acoelomates and the position of Gnathostomulida, Cycliophora, Plathelminthes, and Chaetognatha: a combined approach of $18 \mathrm{~S}$ rDNA sequences and morphology. Syst. Biol. 49, 539-562. doi: 10.1080/10635159950127385

Hansen, A. K., and Moran, N. A. (2014). The impact of microbial symbionts on host plant utilization by herbivorous insects. Mol. Ecol. 23, 1473-1496. doi: $10.1111 /$ mec. 12421

Huang, D., Vannier, J., and Chen, J. (2004). Recent Priapulidae and their early Cambrian ancestors: comparison and evolutionary significance. Geobios 37, 217-228. doi: 10.1016/j.geobios.2003.04.004

Huelsenbeck, J. P., and Ronquist, F. (2001). MRBAYES: bayesian inference of phylogenetic trees. Bioinformatics 17, 754-755. doi: 10.1093/bioinformatics/17.8.754

Johnson, M., Zaretskaya, I., Raytselis, Y., Merezhuk, Y., McGinnis, S., and Madden, T. L. (2008). NCBI BLAST: a better web interface. Nucl. Acids Res. 36, W5-W9. doi: $10.1093 / \mathrm{nar} / \mathrm{gkn} 201$

Juretschko, S., Timmermann, G., Schmidt, M., Schleifer, K.-H., PommereningRöser, A., Koops, H.-P., et al. (1998). Combined molecular and conventional analysis of nitrifying bacterial diversity in activated sludge: Nitrosococcus mobilis and Nitrospira-like bacteria as dominant populations. Appl. Environ. Microbiol. 64, 3042-3051.

Koch, H., Abrol, D. P., Li, J., and Schmid-Hempel, P. (2013). Diversity and evolutionary patterns of bacterial gut associates of corbiculate bees. Mol. Ecol. 22, 2028-2024. doi: 10.1111/mec.12209

Li, K., Guan, W., Wei, G., Liu, B., Xu, J., Zhao, L., et al. (2007). Phylogenetic analysis of intestinal bacteria in the Chinese mitten crab (Eriocheir sinensis). J. Appl. Microbiol. 103, 675-682. doi: 10.1111/j.1365-2672.2007. 03295.x 
Loy, A., Arnold, R., Tischler, P., Rattei, T., Wagner, M., and Horn, M. (2008). probe Check - a central resource for evaluating oligonucleotide probe coverage and specificity. Environ. Microbiol. 10, 2894-2896. doi: 10.1111/j.14622920.2008.01706.x

Loy, A., Lehner, A., Lee, N., Adamczyk, J., Meier, H., Ernst, J., et al. (2002). Oligonucleotide microarray for $16 \mathrm{~S}$ rRNA gene-based detection of all recognized lineages of sulfate-reducing prokaryotes in the environment. Appl. Environ. Microbiol. 68, 5064-5081. doi: 10.1128/AEM.68.10.5064-5081.2002

Ludwig, W., Strunk, O., Westram, R., Richter, L., Meier, H., Yadhukumar, et al. (2004). ARB: a software environment for sequence data. Nucl. Acids Res. 32, 1363-1371. doi: 10.1093/nar/gkh293

Manz, W., Amann, R., Ludwig, W., Wagner, M., and Schleifer, K. (1992). Phylogenetic oligodeoxynucleotide probes for the major subclasses of proteobacteria: problems and solutions. System. Appl. Microbiol. 15, 593-600. doi: 10.1016/S0723-2020(11)80121-9

McLean, N. (1985). A coccidium, a bacterium and two viruses in Priapulus caudatus (Priapulida). J. Invertebr. Pathol. 46, 343-345. doi: 10.1016/00222011(85)90080-1

Nilsson, A., and Fänge, R. (1967). The digestive fluid of Priapulus caudatus (Lam.). Comp. Biochem. Physiol. 22, 927-931. doi: 10.1016/0010-406X(67)90783-9

Nyholm, S. V., and Graf, J. (2012). Knowing your friends: invertebrate innate immunity fosters beneficial bacterial symbioses. Nat. Rev. Microbiol. 10, 815-827. doi: 10.1038/nrmicro2894

Pechenik, J. A. (2015). Biology of the Invertebrates, 7th Edn. New York, NY: McGraw-Hill Education.

Pruesse, E., Peplies, J., and Glöckner, F. O. (2012). SINA: accurate high-throughput multiple sequence alignment of ribosomal RNA genes. Bioinformatics 28, 1823-1829. doi: 10.1093/bioinformatics/bts252

Qu, S. X., Li, H. P., Ma, L., Hou, L. J., Lin, J. S., Song, J. D., et al. (2014). Effects of different edible mushroom hosts on the development, reproduction and bacterial community of Tyrophagus putrescentiae (Schrank). J. Stored Prod. Res. 61, 70-75. doi: 10.1016/j.jspr.2014.12.003

Quast, C., Pruesse, E., Yilmaz, P., Gerken, J., Schweer, T., Yarza, P., et al. (2013). The SILVA ribosomal RNA gene database project: improved data processing and web-based tools. Nucl. Acids Res. 41, D590-D596. doi: 10.1093/nar/gks1219

Schmidt-Rhaesa, A. (2012). Handbook of Zoology. A Natural History of the Phyla of the Animal Kingdom: Gastrotricha, Cycloneuralia, Gnathifera, Priapulida. Berlin: De Gruyter Verlag.
Stackebrandt, E., Frederiksen, W., Garrity, G. M., Grimont, P. A., Kämpfer, P., Maiden, M. C., et al. (2002). Report of the ad hoc committee for the reevaluation of the species definition in bacteriology. Int. J. Syst. Evol. Microbiol. 52, 1043-1047. doi: 10.1099/00207713-52-3-1043

Stamatakis, A. (2006). RAxML-VI-HPC: maximum likelihood-based phylogenetic analyses with thousands of taxa and mixed models. Bioinformatics 22, 2688-2690. doi: 10.1093/bioinformatics/btl446

Stoecker, K., Dorninger, C., Daims, H., and Wagner, M. (2009). Double labeling of oligonucleotide probes for Fluorescence In Situ Hybridization (DOPE-FISH) improves signal intensity and increases rRNA accessibility. Appl. Environ. Microbiol. 76, 922-926. doi: 10.1128/AEM.02456-09

Vannier, J. (2012). Gut contents as direct indicators for trophic relationships in the Cambrian marine ecosystem. PLOS ONE 7:e52200. doi: 10.1371/journal.pone. 0052200

Wang, Y., Stingl, U., Anton-Erxleben, F., Zimmer, M., and Brune, A. (2004). 'Candidatus Hepatincola porcellionum' gen. nov., sp. nov., a new, stalk-forming lineage of Rickettsiales colonizing the midgut glands of a terrestrial isopod. Arch. Microbiol. 181, 299-304. doi: 10.1007/s00203-004-0655-7

Yarza, P., Yilmaz, P., Pruesse, E., Glöckner, F. O., Ludwig, W., Schleifer, K. H., et al. (2014). Uniting the classification of cultured and uncultured bacteria and archaea using 16S rRNA gene sequences. Nat. Rev. Microbiol. 12, 635-645. doi: 10.1038/nrmicro3330

Yilmaz, L. S., Parkernar, S., and Noguera, D. R. (2011). mathFISH, a web tool that uses thermodynamics-based mathematical models for In Silico evalulation of oligonucleotide probes for fluorescence in situ hybridization. Appl. Environ. Microbiol. 77, 1118-1122. doi: 10.1128/AEM.01733-10

Conflict of Interest Statement: The authors declare that the research was conducted in the absence of any commercial or financial relationships that could be construed as a potential conflict of interest.

Copyright (c) 2016 Kroer, Kjeldsen, Nyengaard, Schramm and Funch. This is an open-access article distributed under the terms of the Creative Commons Attribution License (CC BY). The use, distribution or reproduction in other forums is permitted, provided the original author(s) or licensor are credited and that the original publication in this journal is cited, in accordance with accepted academic practice. No use, distribution or reproduction is permitted which does not comply with these terms. 